AL IBTIDA: JURNAL PENDIDIKAN GURU MI (2020) Vol 7 (2) : 264-279

DOI: http://dx.doi.org/10.24235/al.ibtida.snj.v7i2.6832

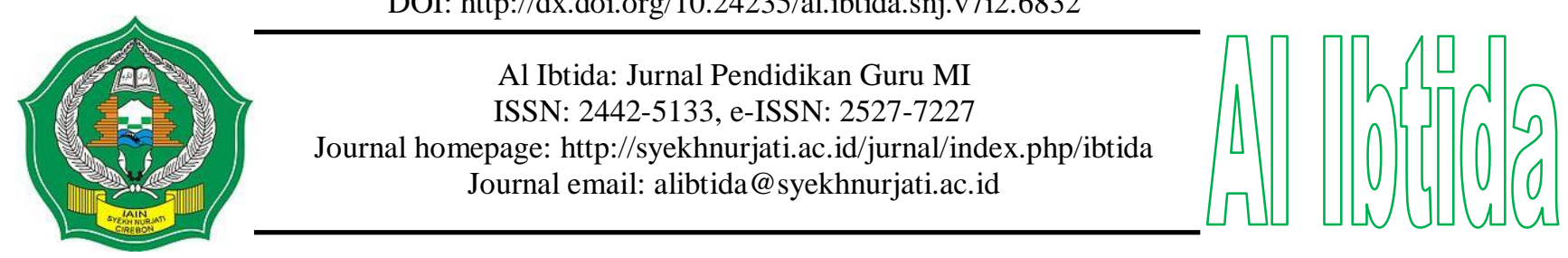

\title{
Humanization of Education in the Challenges and Opportunities of the Disruption Era at Nahdlatul Ulama Elementary School
}

\author{
Ahmad Tarmizi Hasibuan* \\ *Master Program of Madrasah Ibtidaiyah Teacher Education, Faculty of Tarbiyah and Teacher Training, \\ Universitas Islam Negeri Sunan Kalijaga Yogyakarta, Indonesia \\ Email: roszi0508@gmail.com
}

Nurzakiah Simangunsong**

**Master Program of Madrasah Ibtidaiyah Teacher Education, Faculty of Tarbiyah and Teacher Training, Universitas Islam Negeri Sunan Kalijaga Yogyakarta, Indonesia

Email: simangunsongnurzakiah@gmail.com

\section{Ely Rahmawati****}

***Master Program of Madrasah Ibtidaiyah Teacher Education, Faculty of Tarbiyah and Teacher

Training, Universitas Islam Negeri Sunan Kalijaga Yogyakarta, Indonesia

Email: eyrahma13@gmail.com

\author{
Rahmaini $^{* * * * * *}$ \\ *****Department of Islamic Educaiton, Faculty of Tarbiyah and Teacher Training, \\ Universitas Islam Negeri Sumatera Utara, Indonesia \\ Email: rahmaini@uinsu.ac.id
}

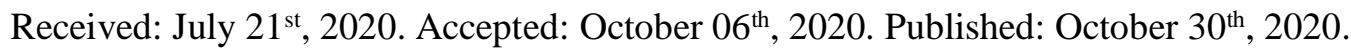

\begin{abstract}
This study was intended to describe the concept of humanization of education which is implemented at the Nahdlatul Ulama Elementary School (SD NU) Sleman Yogyakarta in facing challenges and opportunities in the era of disruption. This type of research is qualitative in the form of a phenomenological approach. In collecting data, researchers used observation, interview, and documentation techniques. Meanwhile, the research data were analyzed using Miles and Huberman model and validated through data triangulation techniques. The results showed that in implementing humanist education at SD NU Sleman Yogyakarta, the school used Sab'atu Ansitoh (7M) activities. They are first, cultivating and instilling behavior; second, grounding the NU pledge of allegiance; third, practice riyadhoh; fourth, improving school facilities; fifth, training educators; sixth, making educators prosperous; and seventh, providing a child-friendly canteen (iqomatil maqsof). It is expected that applying these 7 principles (sab'atu ansitoh) can have implications for improving the quality of students who are able to face the challenges in the era of disruption.
\end{abstract}

Keywords: disruption era, humanization of education, Nadlatul Ulama elementary school. 


\begin{abstract}
Abstrak
Penelitian ini bertujuan untuk mendeskripsikan konsep humanisasi pendidikan yang diimplementasikan di Sekolah Dasar Nahdlatul Ulama (SD NU) Sleman Yogyakarta dalam menghadapi tantangan dan peluang di era disrupsi. Jenis penelitiannya adalah kualitatif dengan pendekatan fenomenologis. Dalam pengumpulan data, peneliti menggunakan teknik observasi, wawancara, dan dokumentasi. Sementara itu, data hasil penelitian dianalisis menggunakan analisis data model Miles dan Huberman dan uji keabsahan data menggunakan teknik triangulasi data. Hasil penelitian menunjukkan bahwa dalam mengimplementasikan pendidikan yang humanis di SD NU Sleman Yogyakarta, pihak sekolah menggunakan kegiatan Sab'atu Ansitoh (7M), yaitu pertama, membudayakan dan menanamkan adab; kedua, membumikan Ikrar kesetiaan NU; ketiga, mentradisikan riyadhoh; keempat memajukan fasilitas sekolah; kelima, melatih pendidik; keenam, mensejehterakan pendidik; dan ketujuh, menyediakan kantin (iqomatil maqsof) ramah anak. Diharapkan dengan menerapkan 7 prinsip (sab'atu ansitoh) tersebut dapat berimplikasi terhadap peningkatan kualitas siswa yang mampu menghadapi tantangan di era disrupsi.
\end{abstract}

Kata kunci: era disrupsi, humanisasi pendidikan, Sekolah Dasar Nahdlatul Ulama.

\title{
INTRODUCTION
}

This disruptive era is known as the openness and challenge era since it asks for the quality and quantity of human resources. According to Utari, Degeng, and Akbar (2016), the disruptive era have a powerful influence for changing people's lives because the technological innovation in all sectors made competition more intense. Besides, technological advances made automation possible in almost all areas. New technologies and approaches that combine the physical, digital, and biological worlds will fundamentally change human patterns and interactions (Nwineh \& Okwelle, 2018). Consequently, technological progress must be offset by relevant policies so that it would be able to create opportunities in the future.

Technology has a negative effect on elementary children when overused. One of negative effect is a drop in the character of primary-age children. UNICEF (2009) has explained that $80 \%$ of elementary school students have experienced bullying both physically and mentally and the majority occur in the classroom. This can cause students to feel scared and depressed in the classroom and outside the classroom (Susanti, Hayati Ifroh, \& Wulandari, 2018) .

In Indonesia, especially in elementary schools there are often cases of violence against children (Bertiani \& Hariwijaya, 2009). Based on data from the Indonesian Child Protection Commission (KPAI, 2016), there was an increase of about 1,000 cases of violence in 2016. Of those 1000 cases, there were 136 cases of child abuse caused by the influence of social media. Technology development trends make social media the main source of violence today, especially among children (Mulyana, Resnawaty, \& Basar, 2018). This matter was very surprising for education experts. In education settings, schools should be a safe place for 
students. But in reality, there is still a lot of violence occur in several schools committed by educators against student in the school environment (Meier, 2019).

Violence against participants does not only occur in the school environment, but even in the family which can be seen from several cases such as domestic violence which makes children as victims (Mawardi, 2008). This incident resulted in a decrease in character in children (Ellis \& Manning, 2019). Therefore it is necessary to innovate in an institution including schools. Education in schools should apply and develop humanistic learning that emphasizes the creation of a comfortable and pleasant learning atmosphere by paying attention and collaborating on the potential of the child in accordance with the physical and psychological development of the soul and soul (Harlin \& Manning, 2009). Not only in the schools, in the community even though every human being must be able to give priority to affection that prioritizes comfort and protection of children.

The above facts need to be overcome in accordance with the way of humanizing human beings in the world of education called education humanization (Zuchdi, 2004). Humanization of education needs to be done to develop the talents and potential of students, so that they are able to grow and develop into humans (educators-students) in full accordance with the objectives of national education (Bialik \& Fadel, 2015). According to Demchenko (2015), inclusive education is one way to create humanism for an even education regardless of age, sex, affiliation or ethnicity, but by taking into account the abilities and development of each individual. This is in accordance with the humanization of education in the European Union such as Germany, Austria, Italy, Finland, Russia, Ukraine, Belarus and Eastern European countries that are members of UNESCO for inclusion in the field of education according to the "Salamanca Declaration" and "Convention on the Rights of Persons with Disabilities (CRPD)" (Golz, Reinhard, Graumann, \& Whybra, 2019).

The Humanization of education aims at forming spiritual intelligent, intelligent of reasoning and emotional of smart child in the stand against this disruptive age (Peter J. Mc. Charty, 2011). At least it should be noted that humanistic learning emphasizes on creating a comfort learning atmosphere by paying attention, integrating potential talents of the students and connecting them to their development and growth (Van, 2009).

In essence, various policies are carried out to humanize the humans. In this study, it is said that to create humanism are by means of habituation, training of educators, and the provision of facilities that can create humanism education. Regarding the methods used to humanize children, it can be done through interactions between teachers and students. So that teachers are expected to understand the essence of children's education which has an impact 
on the growth and development of children's minds. The solution that can be done are (1) the teacher must be adapted to each child, (2) each child has its own talents, (3) learning is linked to the child's real life, (4) learning must be adjusted to the children's interests, (5) the teacher must understand and recognize the nature and characteristics of each child, (6) reduce stressful learning against children, (7) free children to learn based on the child's own experiences and findings, (8) every teacher must learn to humanize children (Shih, 2018).

Nahdlatul Ulama Elementary School (SD NU) of Sleman Yogyakarta have concerned to clean up and keep trying to innovate for the realization of humanization of education. This study was intended to describe the concept of humanization of education which is implemented in the Nahdlatul Ulama Elementary School (SD NU) of Sleman Yogyakarta in facing challenges and opportunities in the disruption era.

\section{METHODS}

This study uses a type of qualitative research in the form of phenomenological approach. This study describes the phenomenon that exists at Nahdlatul Ulama Elementary School (SD NU) of Sleman Yogyakarta related to the activities of how the school implements the concept of humanization education. The study was conducted for three months, starting from September 1, 2019 to December 1, 2019. The subjects in the study consisted of data and data sources. The data in this study is the result of observations in the field, the results of interviews with informants and the results of documentation studies. Meanwhile, data source in the study was focused into two parts, namely the primary data source which were obtained from 2 teachers of Tahfidzul Qur'an, the class teacher of each grade level, and all students from grade I to grade VI. Meanwhile, secondary data source obtained from the principal and the guardian of the three randomly selected students' parents.

Data collection techniques are an important step in research in the context of obtaining data (Sugiyono, 2008). The study collected the data through observation, semi-structural interviews and documentation. After obtaining the data through the data collection tool, the next step is to analyze the data. In analyzing the data, researcher uses Miles and Huberman model data analysis model which consists of reducing data, presenting data, and drawing conclusions. In testing the validity of the data, researchers used triangulation techniques from both source, technique and time. 


\section{RESULTS AND DISCUSSION}

School is a key to success in realizing human resources. The human resources in question are not ordinary human resources but qualified human who are capable of certain competences in the era of disruption. The quality of students will be seen if the educator is able to create a learning atmosphere that is comfortable, calm and promotes children's rights, so that they can compete in the era of disruption and meet the goals of national education. To achieve the educational humanization, Nahdlatul Ulama Elementary School (SD NU) of Sleman Yogyakarta begin to improve teh sector by innovating a number of activities, such as implementing a number of activities namely Sab'atu Ansitoh (7M). The 7 activities are described as it follows:

\section{Cultivate and Embed Adab}

Education does not only explain on how to guide, teach, and train but also how to cultivate and instill goodness (Observation, Friday, June 21, 2019 at 09.00 WIB at SD NU Sleman Yogyakarta). Cultivating and instilling a virtue are not easy for an institution or school. Schools generally become a place for humans to be demanded to prioritize comfort in interacting. Interaction will look good, if the feedback obtained is good (Mansur, 2016). Therefore the task of educators is not only to become educators, instructors and trainers, but educators must better understand the characteristics of their students, especially during interraction.

Good interaction is expected to answer the challenges of 21 st century known as the era of knowledge, so as to create quality human resources (students) who are able to compete in the era of openness (Turyev, 2019). Thus, educators must be able to interact or communicate well, in order to create an atmosphere of learning in the school environment in the era of disruption. The era of disruption is marked by technological developments; making it easier for students to find information and knowledge (Wijaya, Sudjimat, \& Nyoto, 2016). Information and knowledge fuse so quickly in the event that ask for the quality of human resources, so that the role of educators will shift from what used to be a place to ask questions, more or less will merge in the dimension of "space and time", so the task of educators will be so heavy to create a comfotable learning atmosphere (Ellis, Steadman, \& Trippasted, 2019).

Comfortable and quiet learning will be seen when educators play an active role in the learning process to achieve national education goals (Bafadal, 2004). The aim of national education is also to emphasize in producing human resources who are able to compete in the 
world of skills for the future. The era of disruption is an event that demands the quality both in mastering technology and other capabilities that are still in the digital realm.

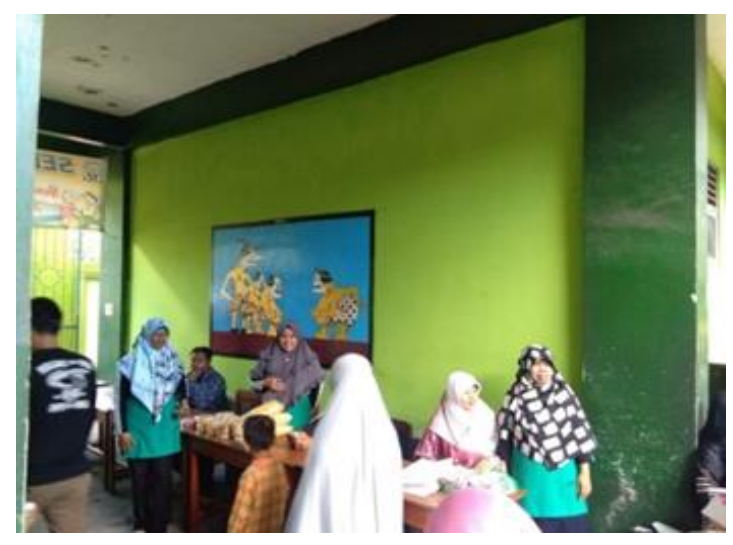

Figure 1. Interaction of Educators and Students in School

Therefore, SD NU Sleman Yogyakarta wants to realize educational humanization in its challenge of asking for quality students. To make it real, the school have done some efforts through civilizing and instilling manners such as greetings, smiles, greetings, politely and politely or called $5 \mathrm{~S}$. Cultivating and inculcating $5 \mathrm{~S}$ are highly recommended by the head of SD NU Sleman Yogyakarta. Through those strategies, they hope students could be able to provide a special approach to (Observation, Friday, June 21, 2019 at $09.00 \mathrm{WIB}$ at SD NU Sleman Yogyakarta).

The above statement is in accordance with the statement of the principal stating that: The role of the leader must be able to adjust digital and technological developments. One of innovations that can make students comfortable and calm is by creating educational humanization (Henderson, 2017). Humanization of education will make children's rights channeled and feel the learning process that is comfortable and quiet in accordance to their growth and development. Responding to the humanization of education, each educator use their own way to make it happen such as cultivating and instilling greetings, smiles, greetings, courtesy and courtesy which are often abbreviated as 5S. (Interview with Principal, Friday, June 21, 2019 at 09.00 WIB at SD NU Sleman Yogyakarta).

The above proposition illustrates the seriousness of the principal in addressing the era of openness or globalization. The era of globalization actually requires students to be more competent or in other words, put more emphasis on quality. Therefore educators must be able to demonstrate their quality as educators, so that the learning process makes it easy for students to understand the lesson.

This is in line with the statement of the guardians of class IV-A which states that: Nowadays, students are really connected to the technology used which they use in daily life such as mobile phone. Mobile phone has become an "opiate" at the level of life, so it can 
change the habits that are carried out in life. Life now has made humans more sophisticated. That is, humans must be more serious in using technology, if they do not want to slip in it. Educators whose initial task is to educate, teach, and train must be able to adjust the existing conditions to make it easier to connect all knowledge, so that it does not become an obstacle feared by educators. For this reason, school principals are now teaching educators to be friendlier between educators and students by cultivating greetings, smiles, greetings, polite and polite, so as to be able to realize the competency in humanization of education and be able to compete in the technological era. (Interview with Homeroom Teacher IV-A, Wednesday, July 3, 2019 at 10:00 WIB in the park environment at SD NU Sleman Yogyakarta).

The above proposition can be concluded that the desire of principals, educators and parents are very great in creating humanization of education that are able to form intelligent students in harmony with growth and development and are expected to be able to compete in the era of disruption that prioritizes the quality of human resources (Nuttall, Henderson, Wood, \& Trippasted, 2020). Forming human resources is not an easy matter, therefore the role of the principal, educators and parents must be in accordance with the era of disruption. In order to realize the humanization of education, school principals, educators and parents must be able to respect the rights of children, and create a comfortable and peaceful learning atmosphere (Cacao, 2013).

SD NU Sleman Yogyakarta must be able to optimize the humanization of education in the era of disruption by cultivating and implanting 5S. Besides, SD NU Sleman Yogyakarta must be more active in carrying out tasks, especially school principals, educators and parents to cultivate greetings, smiles, greetings, courtesy and courtesy or often referred to as $5 \mathrm{~S}$. Through this effort, SD NU Sleman Yogyakarta is expected to be able to realize educational humanization in the era of disruption that can respect the rights of students to create a comfortable and calm learning atmosphere and be able to form quality students to face the challange of new era.

\section{Grounding the Pledge of Allegiance of Nahdlatul Ulama}

SD NU Sleman Yogyakarta is a school that upholds promises. The promise or pledge is always spoken by students after praying and before starting the lesson. Before starting the lessons the school strives to preserve the Nahdlatul Ulama pledge. The school is trying to do the best effort to make their students truly be a proud generation, to be able to compete in the era of disruption. Schools strive to uphold and continually try to implement a pledge of loyalty so that it is embedded in the souls of students as a form of respect. Furthermore, 
students will recite the pledge of loyalty to Nahdlatul Ulama before learning in class, the students of SD NU Sleman are required to memorize pledge of loyalty (Observation, Friday, June 21, 2019 at 09.00 WIB at SD NU Sleman Yogyakarta).

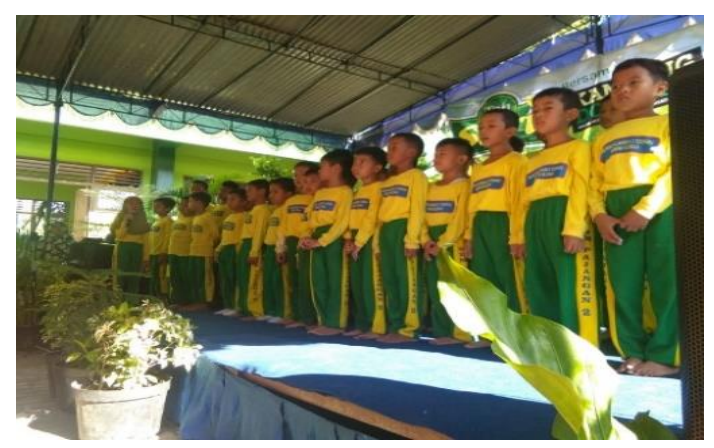

Figure 2. Uttering of NU Vows before Enterring the Classroom

The loyalty pledge meant include: First, giving thanks to Allah Subhanahu Wata'ala by way of prayer, the second, Nation States of Indonesia (NKRI) are things that must be fought by Indonesian Muslims. This matter was implanted in the flag, scout and silat ceremony. The third, NUs supported the 1945 Law and Pancasila was the basis of the Indonesian State. Through this effort, preserving NU's pledge of loyalty in schools is expected to be able to shape students to become a generation who are ready to compete to face the challenges of the disruption era (Observation and Interviews with Headmaster, Friday, 21 Juni 2019 at. 09.13 WIB at SD NU Sleman Yogyakarta).

Based on the challenges faced in the era of disruption, the school seeks to ground and instill a pledge of NU loyalty for students in order to create the development of intelligent and civilized students in accordance with national education goals. Civilization is the key to success in realizing humanization of education that can fulfill children's rights and create an atmosphere of learning. To be able to realize the humanization of education in the face of the era of disruption, SD NU seeks to preserve the values contained in the pledge of loyalty.

\section{Directs Riyadhoh}

SD NU Sleman Yogyakarta is an elementary school that strives to turn their students into quality and knowledgeable human beings. This is in accordance with the policies set by the school and all components in the NU school, namely educators, administrators, security guards and everything in the school. All components in the school combine to realize the Islamic generation. SD NU Sleman Yogyakarta sets rules every morning from 06.30 West Indonesian Time religious activities namely habituation or "Riyadhoh". The activity begun with the Dhuha prayer, dhikr, reciting the names of Allah (Asmaul Husna), as well as praying consisting of the Dhuha prayer, pray togather (between educators and students). In this Riyadhoh activity, the educator voices the students to use the attribute of complete prayer and 
will be imitated by one of the students, after that dhikr and pray and recite the "Asmaul Husna" instructed by the educator, after that is the activity of memorizing the short surah or juz 30 and ends with humming the Qur'an, then memorizing or "muraja'ah" made by students in the class, to be reported with their respective class guardians. All series of activities carried out together. This habituation or "Riyadhoh" activity is carried out in the school field consisting of grades I through grade III, while students in grades IV, V, while grade VI are carried out in the Mosque (Observation, Thursday, June 19, 2019 at .08 .00 WIB at SD NU Sleman Yogyakarta).
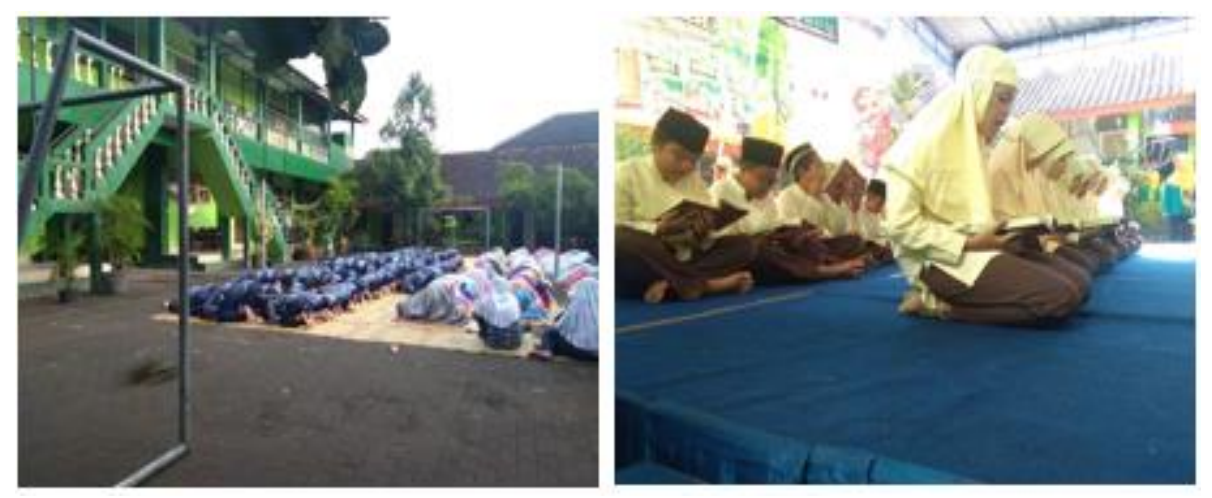

Figure 3. Riyadhoh in SD NU Sleman Yogyakarta

Those facts are supported by the statement of guardians of class VI-A which states that: Habituation or activities in Islam are often referred to as riyadhah. This activity is carried out for the purpose of habituating students themselves. The school or the principal are trying to instill good habits for students, and to facilitate children in learning. Although the school still have little number of students, but they believes that with this habituation will greatly affect the lives of students in the future. Thus, through this habituation, the children can be able to compete in the current era. (Interview with Guardian of Class VI-A, Monday, July 8, 2019 at 09:00 WIB at SD NU Sleman Yogyakarta).

The above statement is strengthened by the opinion of Tahfidz Alquran teacher who said that: Since changing leadership or school principals, then activities that are used to educate children in accordance with the age of growth and development. The growth and development of students must be considered by educators, not least in the current era, which is known as the era of globalization which is marked by the development of science and technology (Kay, Wood, \& Nuttal, 2019). The development of technology makes educators aware of their task of creating intelligent students so that quality of children are formed in accordance with educational goals. That is, educators must have a foresight in creating a comfortable and peaceful learning atmosphere in order to be able to form intelligent intellectuals in accordance with the era. The development of the times prioritizes quality over 
quantity. Therefore educators must be able to create a comfortable learning atmosphere so that they can realize educational humanization in accordance with the era of globalization. (Interview with Tahfidz Alquran Teachers, Monday, July 8, 2019 at 10.15 WIB at SD NU Sleman Yogyakarta).

Based on the two propositions above, it can be concluded that the era of globalization or digital, which is often referred to as the era of disruption, is aimed at promoting the quality of human resources. Educators should be able to recognize the interests, talents and potential of students so that they are able to develop the potential possessed by students. SD NU Sleman Yogyakarta wants to realize the humanization of education by increasing the riyadhoh tradition, by making Dhuha prayers, dhikr, pray, memorize Asmaul Husna and short surahs in the Qur'an that are expected to provide the rights of students fully and are able to realize a school of character in accordance with the desired character of the nation and state.

\section{Advancing Facilities}

In the field of education, schools should be able to create a good learning atmosphere, one way is to improve infrastructure (Interview with the Principal, Thursday, July 10, 2019 at 10.15 WIB at SD NU Sleman Yogyakarta). The parents stated that SD NU Sleman Yogyakarta should be able to realize the humanization of education, because the school already has some adequate infrastructure, such as school buildings, classroom level and a comfortable, cool and quiet environment. Meanwhile, in the context of servicing parents, schools are quite good, such as providing seating for parents who want to pick up their children. Good infrastructure is expected to be the hallmark of the school in the face of some parents' fears in the era of globalization (Interview with the Principal, Thursday, July 10, 2019 at 10.15 WIB at SD NU Sleman Yogyakarta).
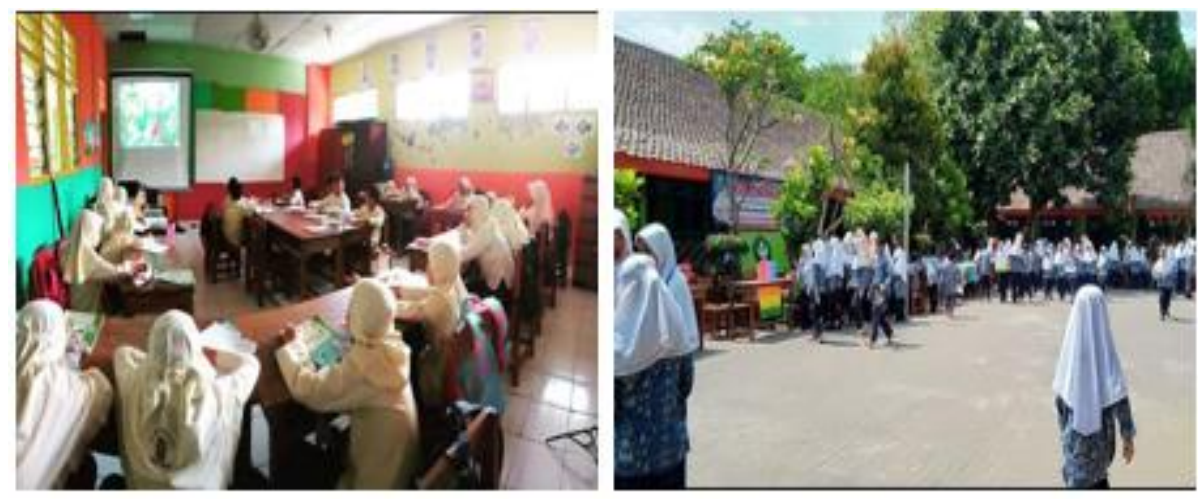

Figure 4. The Environment and Learning Tools of SD NU Sleman Yogyakarta

This is in line with the expert opinion that infrastructure facilities are the first key in realizing the humanization of education, because infrastructure facilities will create an atmosphere that places the rights of students in the teaching and learning process. This 
principle is a way that institutions should realize the humanization of education, because without facilities, educators will not be able to form intelligent students who are aligned with educational goals in accordance with the development of the era of challenges characterized by the development of science and technology (Davies \& Furlong, 2001). To face the technological era, people must have adequate infrastructure in developing their potential to achieve learning goals. Good learning will make it easier for students to understand the knowledge achieved or gained. Therefore education does not only talk about the quality of human resources, because if quality human resources should be supported by adequate infrastructure, without infrastructure, educators will not be able to create a comfortable learning atmosphere and will not be able to form high-quality learners in accordance with the demands of industry era 4.0 (Davies \& Furlong, 2001). This era of disruption is expected not to be an obstacle for educators to develop the potention of students. Therefore, the principal of SD NU Sleman Yogyakarta is striving for the realization of humanization of education, in order to be able to provide children's rights for the creation of intelligent and quality intellectuals by increasing adequate infrastructure, in order to be able to provide the rights of students and create a learning atmosphere that comfortable and quiet.

\section{Train Educators}

Quality is a qualification that will determine the direction of educational exclusion. Good institutions will be seen from good infrastructure, but must also be supported by qualified educators (Interview with Principal, Thursday, July 10, 2019 at 10.15 WIB at SD NU Sleman Yogyakarta). The quality of educators is seen when it is able to create an atmosphere of learning which could attract students' interest. Students are learners who want to keep learning, so that awareness is embedded in learning for the development of academic people. To form learners or the creation of intelligent children, qualified educators are needed. Thus, the role of the principal is very important in training, adding and prospering educators according to the needs and challenges of the disruption era (Suryadi, 2002).
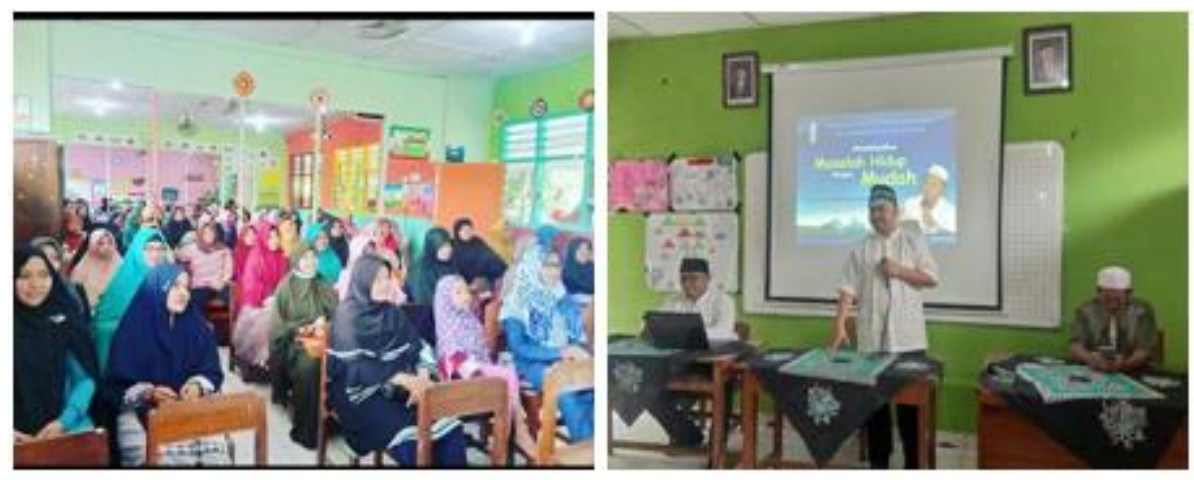

Figure 5. Vocational Training 
Human resources are actually needed in realizing an intelligent nation to compete in the era of challenges (Mangkunegara, 2011). The era of challenges is well known as the era of openness characterized by easy access to information and the very rapid development of technology; making it easier for educators and students to process information. To realize good quality education, qualified and competent educators are needed, so as to be able to realize intelligent students.

The principal of SD NU Sleman Yogyakarta is very aware of the challenges of technological development or the era of disruption. Therefore, the principal strives to increase the quality of educators by facilitating educators and providing them training to create educational humanization (SRA) at the SD NU Sleman Yogyakarta.

\section{Welfare of Educators}

Educators are one element who are able to sustain students in the learning process. Educators have an important role in growing and developing the talents of students. First, as a teacher, educators must be able to manage classes, so students are able to be active in creating and becoming independent (Interview with Teacher, Thursday, July 10, 2019 at 10.15 WIB at SD NU Sleman Yogyakarta). Secondly, as a mentor, professional educators are not only able to convey or transfer knowledge, but rather to develop the talents and potential of students according to their development and growth needs. Third, as a trainer, the essence of training is the task of educators as a whole to prepare quality human resources in the challenges and opportunities in the era of disruption. Therefore, the central point in realizing quality human resources are not only parents, but educators are involved in it. So that the important role is held by the whole teacher in formal education, especially in the elementary school level (Nuttall et al., 2020).

Based on the above proposition, educators should be taken into account and valued for the sake of fulfilling the tasks and the mandate to the fullest. So the consequences are not supported by professional allowance, professional educators will not be realized as has been mandated in the declaration that educators are professions that guarantee the quality of the country.

\section{Provides Child-Friendly Canteen (Iqomatil Maqsof)}

Schools must create a comfortable and conducive atmosphere so that students can express their potential (Kristanto, Ismatul, \& Karmila, 2011); (Kurniawan, 2019). Humanization of education must have healthy food; not containing harmful ingredients to be consumed for the health of students in a way such as schools must provide understanding or knowledge to eat good food and choose healthy foods or snacks. As an effort to realize the 
humanization of education, SD NU Sleman Yogyakarta did or changed several existing systems, such as school principals make policies to children, so that they could not eat or eat at random (Interview with Teacher, Thursday, July 10, 2019 at 10.15 WIB at SD NU Sleman Yogyakarta). To support these activities, the school makes an appropriate program, that is, the school cooperates with outsiders to make snacks for food in the morning and afternoon for students, with the aim that children eat food that does not harm the body (Nuttal, 2020).

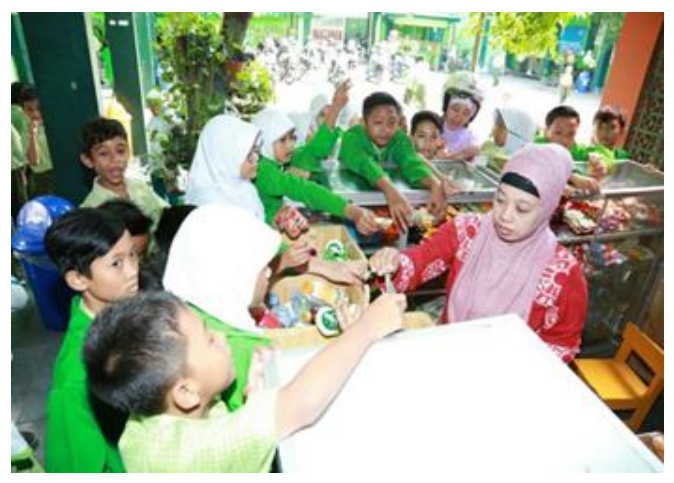

Figure 6. Child-Friendly Canteen (Iqomatil Maqsof)

Therefore, SD NU Sleman Yogyakarta manages the food system for all students called the "healthy eating" program. This program is the policy of the principal supported by educators. To support the "healthy eating" program, the school has knowledge about balanced nutrition, food safety, and properly and correctly food production. Knowledge of healthy food and balanced nutrition are needed in food processing and preparing daily menus in accordance with the needs of elementary school students in harmony with development and growth, so that the participants of SD NU Sleman Yogyakarta are fulfilled their nutritional needs and they are not bored of consuming healthy food at school by paying attention to the development and growth of elementary school children. For this reason, the principal's policy is expected to be able to be channeled properly, in order to facilitate the realization of educational humanization (Observation, Thursday, July 10, 2019 at 10.15 WIB at SD NU Sleman Yogyakarta).

The principal and educators and school components have an important role in directing the program of "healthy eating", so that they can pay attention and provide healthy, nutritious and balanced food in accordance with the development and growth of students (Meier., 2019). Foods are very important or one that determines and influences a lot of students' health. So with this canteen program, it is expected that it could be able to realize the awareness of students in buying snacks or food, in order to avoid hawking or not healthy body. Besides, this canteen program is expected to be able to realize educational humanization that prioritizes the rights of students, and can be a distinctive feature for the SD NU Sleman Yogyakarta. The 
effort to stop the canteen is expected to be the hallmark of SD NU Sleman Yogyakarta to create educational humanization in the era of disruption.

\section{CONCLUSION}

Schools are the key to success in realizing human resources. The human resources in question are not ordinary human resources but high quality human resources. The quality of students could be seen if educators are able to create a comfortable and calm learning atmosphere that prioritizes the rights of students, so that they can compete in an era of challenges of the era of disruption. and to create educational humanization. To realize the humanization of education, SD NU Sleman Yogyakarta began to improve by seeking various methods, such as by implementing the $7 \mathrm{M}$ system, namely: civilizing and naming adab, grounding the pledge of loyalty to nahdatul ulama, rebirth riyadhoh, advancing facilities, training educators, welfare educators, and providing canteen. (iqomatil maqsof) child friendly. It is hoped that applying these 7 principles (sab'atu ansitoh) can have implications for improving the quality of students who are able to face the challenges of the era of disruption.

\section{REFERENCES}

Bafadal, I. (2004). Improvement of MI Teacher Professionalism in Madrasah Based Quality Management. Jakarta: Earth Literacy.

Bertiani, S., \& Hariwijaya. (2009). PAUD Jumps Up Children's Potential With Early Education. Yogyakarta: Mahadika Publishing.

Bialik, M., \& Fadel, C. (2015). Skills for the 21st Century: What Should Students Learn? Center for Curriculum Redesign. Boston: Massachusetts.

Cacao, M. I. (2013). Teacher Education challenges for Schools of Education: Pragmatism and Simplification. Journal Arquivos Analíticos de Políticas Educativas, 21(84). Retrieved from https://doi.org/10.14507/epaa.v21n84.2013

Davies, \& Furlong, J. (2001). Young People, New Technologies and Learning at Home: Taking Context Seriously. Oxford Review of Education, 38(1), 1.

Demchenko, I. (2015). The essence of the concept of "inclusive pedagogy". http://dspace.udpu.org.ua

Ellis, V., \& Manning, M. S. (2019). Innovation in teacher education: Towords a critical reexamination. Journal of Education for Teaching, 45(1). Retrieved from https://doi.org/10.1080/02607476.2019.1550602.

Ellis, V., Steadman, S., \& Trippasted, and T. A. (2019). Teacher Education and the GERM: Policy Entrepreneuship, Disruptive Innovation and the Rhetorics of Reform. Journal Educational Review, 71(1). Retrieved from https://doi.org/10.1080/00131911.2019.1522040

Golz, Reinhard, Graumann, O., \& Whybra, D. (2019). The Humanization of Education: Some Major Contemporary Challenges for an Innovative Concept. International Dialogues on Education., 6(2). 
Harlin, R., \& Manning, and M. S. (2009). Review of Research: Educating Latino Children: International Perspectives and Values in Early Education. Journal Childhood Education, 85(3). Retrieved from https://doi.org/10.1080/00094056.2009.10521388

Henderson, L. (2017). Someone Had to Have Faith in Them As Professionals': An Evaluation of An Action Research Project To Develop Educational Leadership Across The Early Years. Journal Education Action Research, 25(3). Retrieved from https://doi.org/10.1080/09650792.2016.1173566.

Kay, L., Wood, E., \& Nuttal, J. (2019). Problematising Policies for Workforce Reform in Early Childhood Education: A Rhetorical Analysis of England Early Years Teachet Status. Journal of Education Policy,. Retrieved from https://doi.org/10.1080/02680939.2019.1637546

KPAI. (2016). Laporan data kekerasan yang dialami oleh anak dalam lima tahun, yaitu dari tahun 2011-2014. https: kpai.go.id.

Kristanto, Ismatul, K., \& Karmila, M. (2011). Identification of Child Friendly School Model (SRA) Level of Early Childhood Education Unit in South Semarang District. Journal: PAUDIA, 1(1), 4.

Kurniawan, A. (2019). Optimization of Humanistic Education in the Integrated Islamic Primary School. Al Ibtida: Jurnal Pendidikan Guru MI, 6(1), 37-48.

Mangkunegara, A. . (2011). Planning and Development of Human Resources. Bandung: Rifeka Aditama.

Mansur, N. (2016). Application of Teaching Skills in Efforts to Achieve Student Learning Outcomes. Lanthanide Journal, 4(1), 1.

Mawardi, K. (2008). Madrasah Banat: Portrait of NU Girls' Education in Dutch Colonial Period. Journal of Gender and Child Studies, 3(2), 24.

Meier., L. T. (2019). NQuestioning the Problematic Nature of School Culture in Elementary Teacher Educationo Title. Journal of Culture and Values in Education, 2(1).

Mulyana, N., Resnawaty, R., \& Basar, G. K. (2018). penangan anak korban kekerasan. Al Izzah: Jurnal Hasil-Hasil Penelitian, 13(1). Retrieved from http://dx.doi.org/10.31332/ai.v13i1.871

Nuttal, J. (2020). Formative Interventions and The Ethics of Double Stimulation for Transformative Agency in Professional Practice. Journal Pedagogy, Culture and Society. Retrieved from https://doi.org/10.1080/14681366.2020.1805498

Nuttall, J., Henderson, L., Wood, E., \& Trippasted, and T. A. (2020). Policy Rhetorics and Responsibilization in the Formation of Early Childhood Educational Leaders in Australia. Journal of Education Policy,. Retrieved from https://doi.org/10.1080/02680939.2020.1739340.

Nwineh, L., \& Okwelle, P. C. (2018). Acquisition of Practical Skills in Domestic Electrical Installation: Computer Simulation Versus Demonstration Approach. Journal of Technical Education and Training (JTET), 10(1). Retrieved from https://10.30880/jtet.2018.10.01.004.

Peter J. Mc. Charty, D. (2011). Parent School Communication in the Inclusive Classroom: A Comprehensive Model of Collaboration in Education International. Journal of Humanities and Social Science, 1(15).

Shih, Y.-H. (2018). Towards a Pedagogy of Humanizing Child Education in Terms of Teacher-Student Interaction. Journal of Education and Learning, 7(3). 
Sugiyono. (2008). Metode Penelitian kunatitatif Kualitatif dan $R$ \& D. Bandung: ALFABETA.

Suryadi, A. (2002). Education, HR Investment, and Development. Jakarta: Balai Pusataka.

Susanti, R., Hayati Ifroh, R., \& Wulandari, I. (2018). Mapping School Bullying pada Aanak di Kota Samarinda dengan EPI MAP. JPH RECODE, 1(2). Retrieved from http://ejournal.unair.ac.id/JPHRECODE

Turyev, K. (2019). Humanising as innovation in a cold climate of (so-called-evidance-based) Teacher Education. Journal Of Education for Teaching, 45(1). Retrieved from https://doi.org/10.1080/02607476.2019.1550603.

UNICEF. (2009). Stop violence against children. UNICEF Malaysia Communications. doi: $10.2174 / 138920312803582960$.

Utari, U., Degeng, I. N., \& Akbar, S. (2016). Thematic Learning Based on Local Wisdom in Elementary Schools Facing the Asean Economic Community (AEC). Journal of Theory and Practice of Social Studies Learning, 1(1), 234.

Van, K. J. J. (2009). Holistic or Sequential Approach to Curriculum: What Works Best for Young Children? Journal: Revista LatinoAmericana En Ciencias Sociales, Niñez Y Juventud, 7(2).

Wijaya, A., Sudjimat, E. A., \& Nyoto, D. A. (2016). Transforming 21st Century Education as Guidance for Human Resource Development in the Global Era. Journal: Malang State University, 1(1), 2.

Zuchdi, D. (2004). Humanization of Education and Development of Conflict Management Skills. Journal of Educational Horizons, 2(2), 49-56. 